This PDF is a selection from an out-of-print volume from the National Bureau of Economic Research

Volume Title: The State of Monetary Economics

Volume Author/Editor: Universities-National Bureau Committee for Economic Research

Volume Publisher: NBER

Volume ISBN: 0-87014-307-7

Volume URL: http://www.nber.org/books/univ65-1

Publication Date: 1965

Chapter Title: The Portfolio Approach to the Demand for Money and Other Assets

Chapter Author: James Duesenberry

Chapter URL: http://www.nber.org/chapters/c5178

Chapter pages in book: (p. 9 - 31) 


\title{
THE PORTFOLIO APPROACH TO THE DEMAND FOR MONEY AND OTHER ASSETS
}

\author{
James S. Duesenberry, Harvard University
}

$\mathrm{T}$ THE theory of the demand for financial assets has come in for a good deal of discussion in the last few years. Undoubtedly the discussion has been fruitful and has given us many new insights into the nature of financial processes. But it cannot be said that there is any generally agreed upon view as to the way in which those processes work. It would be appropriate at a conference of this kind to review the different hypotheses and give a systematic summary of the present state of knowledge. Unfortunately, though I have read the literature assiduously I have found it rather indigestible. I do not feel prepared to give a fair summary of other people's views. I must fall back therefore on giving my own.

In this paper I shall deal with the demand for liquid assets and money by households and corporations. Those two groups hold over twothirds of all liquid assets, and the same general approach though not the details can probably be applied to the demands of unincorporated businesses, farmers, state and local governments. In dealing with the demand for liquid assets we must at least implicitly deal with the demand for other types of assets, but I shall not, except incidentally, say anything in detail about the demand for stocks, bonds, or physical assets. I shall confine myself to the demand for currency, demand deposits, commercial bank time deposits, mutual savings bank deposits, savings and loan shares, savings bonds, and short-term federal securities. There are, of course, other liquid assets, but I shall have little to say about them.

I have occasionally used the term money in the sense of demand deposits and currency but have usually referred to those assets specifically to avoid any confusion with other definitions of money. But though I am happy to try to avoid the semantic confusion involved in arguments about whether any particular asset should be included under the heading money, I do cling to the view that commercial bank time deposits are significantly different from demand deposits. For that matter, so is currency, and so perhaps we ought to dispense with the term money in theoretical discussions and say clearly what we mean.

In the first section of the paper I have discussed very briefly the conditions under which liquid assets are supplied. There follow in section 2 a discussion of corporate motives for holding liquid assets and money and a review of some empirical evidence on the relative importance of various factors influencing corporate decisions. In section 3 , this theory of household demand for liquid assets and money is discussed together with some empirical evidence.

\section{The Supply of Liquid Assets}

The major liquid assets today are cash, short-term government securities, savings bonds, and time deposits at commercial banks, mutual savings banks, and savings and loan associations. Various other assets, e.g., commercial paper, supply some liquidity and, under other circumstances, could supply more, but we shall confine ourselves here to short governments, savings bonds, and time deposits.

Savings bonds are, of course, on tap at fixed yields and may be regarded as exogenously determined.

The total volume of short-term Treasury securities is determined by the Treasury (assuming that it may affect conversions if it wishes). For theoretical purposes, we may regard the composition of the federal debt as an exogenous policy variable. The fact remains, however, that there is some tendency for the proportion of short-term issues outstanding to rise in tight money periods and fall in easy money periods.

If we are concerned with the determinants of nonbank liquid asset holdings, then the willingness of banks to switch maturities becomes important. In general, banks appear to have been willing to switch out of very short 
maturities into somewhat longer ones in response to changes in the yield curve. As a result, the supply of under-one-year maturities to nonbank holders has considerable elasticity in terms of yield spreads, though the supply curve is certainly not flat.

The supply of savings deposits is a very different matter from the supply of Treasury bills and commercial paper. In the short run, the supply of savings deposits is elastic at the announced rates. In the long run (except when the regulatory authorities interfere) the rate offered by savings institutions is related to market rates and operating costs. For savings and loan associations, the relevant rates are mainly those on conventional mortgages in the areas where they operate. For mutual savings banks, yields on mortgages in their own areas, on guaranteed mortgages in other areas, and on bonds which they are eligible to buy are relevant. If legal restrictions on rates did not interfere, commercial bank time deposit rates would presumably tend to reflect yields on mortgages and municipal securities.

In the long run the differentials between savings deposit rates and those available on credit market instruments depend not only on cost factors in bank operations but also on the relative supplies of debt instruments of different types. A large supply of mortgages tends to raise savings institution yields relative to others because those institutions have a comparative advantage in handling mortgages.

If we are content with a partial analysis, the above comments are perhaps sufficient. There are, however, some additional considerations affecting the availability of liquid assets. Let us suppose that for some reason the public's tastes change so that households collectively wish to switch out of other assets into savings deposits. Since savings institutions appear to be willing to take all the deposits they can get at the going rate, there appears to be no reason why the public should not make the switch. But, of course, that is not true. If the yield spreads existing when tastes change are to persist, the savings institutions must not only be willing to take deposits but they must also be willing to buy the assets from which the public wants to switch (if we rule out asset expansion by banks). If the public wished to sell a set of assets having the same relative composition as the existing portfolios of savings institutions, there is no reason why the switch should not take place. But suppose the public wished to sell stocks and take savings deposits. They cannot sell the stocks to savings institutions. In the end the stocks must remain in the hands of holders other than savings institutions. If the initial holders come to like stocks less, their prices must fall until the original or some other holders other than savings institutions are willing to hold them. That change in yields may set up repercussions which will result in some increase in savings deposits (and the shifting of some assets to savings institutions). But even when the yields offered by savings institutions are a fixed function of yield on credit market instruments, the public cannot trade freely between savings deposits and other assets at fixed yields. ${ }^{1}$

We cannot properly analyze the forces influencing the volume of savings deposits in partial equilibrium supply and demand terms. Those forces work themselves out through the whole system of interrelated supplies and demands for different kinds of assets.

\section{Corporate Holdings of Money and Other Liquid Assets}

In this section we shall consider the factors influencing the total amount of liquid assets held by corporations and the division of those assets between cash and interest-bearing forms of liquidity. We start from the assumption that the decision-making process involves first a decision about the amount of liquid assets to be held and then a decision about the proportion to be held in cash.

We begin with a brief outline of the rationale for holding liquid assets and then consider in equally general terms the rationale of the choice between cash and other liquid assets. We then turn to the empirical problem of explaining observed movements of liquid assets. We first review some work which seems to explain the short-term cyclical movements of

\footnotetext{
${ }^{2}$ Of course, the public's holdings of stocks will in the long run be affected by a change in tastes because changes in the yields of stocks relative to other assets will influence the composition of corporate security issues and the composition of investment.
} 
liquidity positions during the postwar period, and then consider the trend of liquidity positions in the postwar period. Finally there are some rather sketchy comments on liquidity movements in the twenties and thirties.

We then turn to the problem of explaining observed movements in the division of liquidity between cash and other forms of liquidity. Once again, we begin with the postwar period and then proceed to comment briefly on the events of earlier periods.

\section{Business Demand for Liquidity.}

Corporate treasurers wish to have liquid assets on hand for a variety of reasons. First, some minimum of liquid assets is required to cover the day-to-day variations in receipts and expenditures without continually borrowing and repaying bank loans. Second, many corporations have wide seasonal variations in their cash inflows and outflows. Some choose to borrow from banks during seasons when cash outflows exceed inflows and repay when the balance of the flows turns the other way. Others, however, raise enough from long-term sources to cover all or part of their seasonal cash outflows, and therefore have surplus liquidity during the seasons of net cash inflow. In doing that they make an interest sacrifice which depends on the relations between the cost of longterm funds, the cost of bank borrowing, and the yield on liquid assets. ${ }^{2}$

Third, most, though not all, business firms seem to feel that it is desirable to fund all or a very large part of their tax liability. A sophisticated treasurer may feel that he need only be prepared to meet the net reduction in tax liability which will occur when profits decline, but most of them do not appear to take that view.

Fourth, most firms wish to have liquidity to meet the problems arising from a decline in cash flow from current operations during a depression. In a depression a firm must be able to draw down liquid assets or borrow to meet the cumulative difference between net cash flow from operations and the sum of (I) debt

\footnotetext{
"In return for that cost they reduce the risk of being burdened with short-term debt during a business decline and reduce the cost of long-term borrowing by improving the current ratio.
}

service (2) dividends (3) a minimum level of investment. It should be noted that net cash flow from operations can become negative because, in order to maintain its market share, a firm is willing to continue production when average variable cost exceeds price.

It is not, of course, strictly necessary to maintain dividends in periods of adversity, but it is clear that many firms are willing to bear some cost in order to do so.

Investment will, of course, decline to a low level during a depression but, even when there is a great deal of excess capacity, certain investments can be avoided only at great cost. Those investments include replacements necessary to maintain production, and investments required to adapt to changing market conditions. In addition, technical developments or the possibility of buying out financially weak competitors may present investment opportunities promising very high returns.

A firm always has the possibility of financing those cash requirements by borrowing, but in a depression lenders may not be disposed to gamble on the firm's prospects. If they are willing to lend they may require some measure of control or impose restrictions on the borrower's action.

To avoid or reduce borrowing under adverse conditions, a firm can raise more long-term capital than it needs for current outlays, during periods when it can do so advantageously, and build up a stock of liquidity against adversity. It then pays the difference between the cost of long-term funds and return on liquid assets (less the cost of borrowing avoided during periods of adversity). The cost may be somewhat reduced because the improvement in its current ratio will reduce the cost of its long-term borrowing.

In all the cases so far mentioned, the firm gains in convenience and reduction of risk by paying more in interest charges than would otherwise be necessary, and the amount of liquidity maintained will be determined at the point where the marginal gains are balanced by the costs of obtaining additional liquidity. That implies, of course, that the amount of liquidity held by the firm will (other things equal) tend to increase as long-term capital 
costs fall relative to the yields on Treasury bills or other short-term investments.

We should, of course, expect business liquidity at a given phase of the business cycle to be roughly scaled to the volume of sales or total receipts and payments - with the proportionality factor varying with interest rate differentials. Since risk is involved, we should expect firms to hold less liquidity as they become more confident of the stability of the economy and to increase liquidity ratios with a deterioration of confidence. Finally, the level of corporate income tax rates and the length of the collection lag should influence the volume of liquid assets held.

Before going on to review some empirical evidence on these propositions, it is necessary to introduce some other considerations.

The variation in corporate liquidity over the cycle reflects some "mechanical" aspects of cash inflows and cash outflows. Firms that do not rely heavily on bank financing will tend to have certain passive inflows and outflows of cash (which may be shifted into other forms of liquid assets). To put it another way, firms may have certain target levels of liquid assets but they do not always eliminate discrepancies between actual and target levels very rapidly.

During recovery years, like I955 and I959, corporations tend to gain liquidity because profits rise rapidly while tax payments lag. Fixed investment appropriations rise rapidly but actual outlays rise more slowly. Inventories and receivables also rise but a considerable part of the increase is bank financed. The result is a large net cash inflow. Firms gaining liquidity in this way could pay off long-term debt, but have little incentive to do so since they are committed to higher investment outlays in the near future and will also have larger tax payments to make.

In the later years of the cycle, retained earnings and depreciation level off, tax payments catch up, and the rate of investment outlays catches up with new appropriations for investment. Some of the liquidity gained earlier is then disgorged.

The record in slump years is mixed. Corporations lost liquidity in 1954 and I960 but gained in 1958. The difference appears to be due in part to ( $I$ ) differences in the relative changes in profits and tax payments arising from changes in the tax law, (2) differences in the magnitude of inventory reduction, (3) differences in the magnitude of the change in plant and equipment investment.

\section{Corporate Demand for Demand Deposits.}

Corporate demand for demand balances has to be explained in terms of the rationale of the choice between demand balances and other types of liquid assets which earn interest in this case, mainly Treasury bills.

As in the case of households, a substantial part of corporate liquidity is held to cover fairly near-term net cash outflows arising from the uneven rates of receipts and expenditures. The gross return to be obtained from holding Treasury bills depends on the amounts involved, the interest rate, and the length of the holding period. The gross return is offset by the transactions cost of going into and out of bills - dealer spread and any other direct costs. However, dealer spreads on bills are very low so that the direct cost of transactions in bills can be earned by holding bills for very short periods even at low interest rates.

However, the direct costs of transactions are only part of the cost of holding Treasury bills. If bills are held only for a few definite, large out payments - e.g., tax payments - the only additional cost is a little thought on the part of the treasurer. But as soon as a firm embarks on a program of trying to earn interest by predicting cash inflows and outflows, and investing temporary excess funds, it has to bear some overhead costs to keep track of its cash position.

In entering on a program of investing shortterm surpluses of funds and in deciding how far to carry it, a firm must balance the expected average return from its bill holdings (or an increment in them) against the overhead cost of controlling its cash position. The expected return will vary with the average rate of interest on bills expected over a period of years. The cost will vary with the tightness of the cash management. As we pass from simple operations such as funding tax liabilities to the very close cash management practiced by a few large companies, the cost of increasing the average amount invested (for a firm on a given 
scale) by closer management will rise. The cost per dollar invested will rise as the scale of the firm becomes smaller. We should expect, therefore, that at low interest rates only large firms will use Treasury bills for any purpose other than funding tax liabilities, and even the large firms may not find very close cash management worthwhile. A rise in interest rates should push out both the extensive (size of firm) and intensive (closeness of cash management) margins and cause a shift from cash to bills. However, since the costs of cash management are mainly overhead costs, we do not expect much shifting between cash and bills in response to short-run fluctuations in bill rate. Instead, we expect shifts in response to changes in the average rate expected for a period of years - probably best measured by a fairly long moving average of past rates. Moreover, some of the costs are costs of getting started and learning the tricks of cash management, so that a rise in bill rates may result in a shift from cash to bills. A later fall (even on a long-term basis) may not bring the cashbill ratio back to its initial position.

Shifting from cash to interest-bearing liquid assets is not the only way to reduce cash balances in relation to activity. Close attention to cash management may enable a firm to reduce its operating cash without any investment. For example, measures to speed up processing and collection of checks may reduce the float of unavailable cash. There are many examples of this sort. It is not clear whether developments of this sort represent a response to changing interest rates or whether they are simply improvements in managerial techniques which, like other changes in techniques, occur even when no factor price has changed. One would expect, however, that enthusiasm for measures to reduce the need for cash would increase with rising interest rates. It should be noted that increased efficiency in the use of operating cash is likely to reduce total liquidity and to affect cash directly so that the share of cash in total liquidity will fall.

Corporate managements also appear to have achieved some reduction in their cash balances in relation to activity by sharper negotiation with banks. It is customary for corporations holding payroll, dividend, or other accounts in- volving a large volume of check processing to maintain an average balance on which the bank can earn a return (in lieu of a service charge), which covers the costs of servicing the account. In recent years, a good many corporations which do not depend on bank loan finance have tried systematically to hold these balances down to a minimum. But, so long as the custom of remunerating banks by holding balances rather than by explicit service charges continues, a substantial amount of corporate funds will be tied up in this way.

\section{Short-Run Movements in Total Liquidity.}

In discussions of the demand for money and liquid assets, attention is usually centered on the elasticity of demand for liquid assets with respect to interest rates. In fact, however, the variation in corporate liquid asset holdings over the business cycle is principally due to variations in the cash flows from operations. Cash flows are generated by retained earnings, plant and equipment outlays, increases or decreases in inventory and variables, tax accounts and tax payments. The net balance of those flows each of which has a large cyclical variation is first reflected in corporate liquid asset holdings. Managements then have to decide whether the resulting liquidity position is too high or too low with respect to some target. If the liquidity position is out of line with this target position, firms must then raise funds from outside sources or repay debt.

Interest rates may enter this picture in two ways. On the one hand, target levels of liquidity may be influenced by the cost of holding liquidity, as indicated above. On the other hand, even if target levels are not affected by interest costs, the timing of borrowing may be influenced by cyclical movements in the interest rate.

Following this reasoning, we may treat liquid asset holdings as an inventory and explain movements in liquidity in terms of a stock adjustment process of the same type used in explaining physical inventories.

This has been done by Locke Anderson in a paper presented to the Econometric Society. Briefly, his results can be interpreted as follows.

r. Target levels of liquid asset holdings ap- 
pear to depend on sales and tax liability, with the desired holdings of liquidity equal to about I 5 per cent of annual sales and 60 per cent of tax liability.

2. The amount of outside funds raised in a quarter (for a given position in terms of other variables mentioned below) increases by about $25 \phi$ for every dollar of increase in the difference between actual and target liquid asset holdings at the start of the quarter. That is, firms act as though they tried to close the gap between actual and target holdings in about a year.

3. Borrowing in a given quarter also responds to changes in cash flows from retained earnings and depreciation, plant and equipment expenditures, and inventories and receivables. Shortterm borrowing declines by about 75 per cent of any increase in retained earnings, but the response of borrowing to cash flows of the other types is much weaker. As a result, an increase in the rate of inventory investment will reduce liquid assets, and vice versa.

4. The rate of borrowing is also significantly influenced by the debt position of corporations.

5. Finally the rate of long-term borrowing is significantly influenced by the corporate bond yield. A one percentage point increase in the bond yield appears to reduce corporate borrowing by $\$ 700$ million per quarter. If all other flow variables remained constant while the bond yield rose, the result would be a decline in borrowing followed by a gradual rise as the liquidity stock was reduced. A one-time rise in the interest rate would result in a onetime reduction in the liquidity stock. However, there are some indications that the relevant interest rate variable is not the absolute rate but some indicator of the cyclical position of the rate. That view is supported by the fact that the bill rate did not appear to have any significant influence on borrowing. Since the cost of liquidity is the difference between bill and bond yield, it seems probable that the interest rate coefficient represents a timing variable rather than a variable affecting the long-term level of liquidity.

Anderson's results are supported not only by aggregate regressions for all manufacturing but also by separate analysis of a number of manufacturing industries. They seem to show, first, that the bulk of the variation in corporate liquidity is explained by variations in operating cash flows. Second, they do show that the interest rate can have a very substantial shortrun effect on corporate borrowing but leave it uncertain whether the upward trend in interest rates plays a significant role in determining the trend of corporate liquidity.

POSTWAR TREND IN TOTAL LIQUTDTTY. We need not give any account of movements of corporate liquidity in the years immediately after the war. It seems reasonable to take the view that most corporations had made their basic adjustment to postwar conditions by about 1952. Since that time there has been 2 downward trend in the ratio of corporate liquid asset holdings to GNIP and to corporate sales.

Part of the decline is probably due to the decline in the ratio of tax liabilities to corporate sales as a result of the decline in profit margins and the shortening of the lag between accrual and payment. The ratio of liquid assets, less tax liabilities, to sales shows almost no decline. However, it is going too far to offset tax liabilities against liquidity, one for one. We know that some corporations borrow at tax dates so they cannot have fully funded their tax liability. Some corporations have less total liquidity than their tax liability, so it is obvious that they cannot have done so. Anderson's research suggests about 60 per cent funding as a norm. If that figure or one somewhere near it is used, then the ratio of corporate liquidity to GNP (adjusted for the tax factor) fell from about .II in I952, to .09 in I960 and I961. The downward drift in the relative holdings of cash, governments, and time deposits may have been offset by an increase in holdings of various other liquid assets not included in our figures, but those other assets cannot have increased enough to offset the downward trend in relative holdings of the ones included.

To what should we attribute the decline? Even if we took Anderson's results with respect to the interest rate at face value, we would expect to get a decline in liquidity of less than I per cent of $G N \mathbb{P}$ from the $1952-6 \mathrm{r}$ rise in BAA bond yields. Moreover, the net cost of holding liquidity has increased very little because the average spread between bill and bond yields has changed relatively little. Rising in- 
terest rates may have had some effect on the trend of liquidity ratios, but it seems doubtful that it has been very large.

Three other factors have probably played a role: (I) improved cash management, partly as a result of higher interest rates but also simply as a part of the general and continuing effort to reduce costs; (2) improved confidence in the stability of the economy may have induced some firms to reduce holdings of liquidity for protective purposes; (3) some firms still had "excessive" liquidity in 1952 and have worked it off since.

I know of no way to measure the influence of these factors but it seems unlikely that more than a fraction of the decline in liquidity ratios is due to changes in interest costs.

\section{Liquidity in the Twenties Compared with Post- war Liquidity.}

The ratio of corporate liquidity to GNP during the 1920's stood at about .I4 until I928, when it rose sharply to .I 7 , returning to about .15 at the end of 1929 . The ruling ratio during the twenties was higher than that ruling in $195^{2}$ (after adjustment for tax liability). Moreover liquidity ratios showed no downward trend during the twenties. The rise at the end of the twenties is probably due to the large volume of stock issues in 1928 and 1929 , and the rise would be even larger if corporate holdings of call loans were included in the ratio.

The net cost of holding liquidity has probably not increased significantly between the twenties and the fifties. Indeed (leaving call loans aside) it has probably decreased because of income tax and the availability of Treasury bills. It does not seem reasonable to argue that people have become more confident about income stability now than they were in the twenties. We can conclude, it seems to me, that the difference in liquidity ratios between the two periods is due to factors other than confidence or the cost of liquidity. It is hardly surprising that changes in the composition of output, in methods of financing, in the concentration of industry, should have produced some substantial changes in liquidity ratios.

It seems unlikely that, interest costs aside, practices with respect to liquidity should fol- low simple and immutable laws over long periods.

Liquidity Movements in the Great Depression. Corporate liquidity rose relative to GNP from the already high level in I 929 to 1932 and 1933. Thereafter liquidity ratios fell slowly, but even at the beginning of World War II the ratio of corporate liquid asset holdings to GNP was .I6. With some allowance for corporate tax liability, the corporate liquidity ratio in I94 I was near the level of the I920's.

It seems probable that most of the swing in liquidity during the thirties was attributable to the confidence factor. Firms preferred to hold on to liquid assets in the early thirties rather than pay back debt, because the chance that economic conditions would deteriorate was taken very seriously. With recovery, firms permitted liquidity ratios to decline gradually. The movements of liquidity ratios conform much more closely to one's guess about the state of business confidence than to the variations in the net interest cost of holding liquidity.

\section{Cash Versus Other Forms of Liquid Assets in the Postwar Period.}

In the years since $195^{2}$, corporate cash holdings have increased slowly and steadily, while holdings of governments have shown little trend and have varied from year to year in a range of about $\$ 3$ billion. Another set of regression studies by Anderson suggests that most of the short-term variations in liquidity positions are reflected in holdings of government securities, while cash positions respond much more weakly to those factors. It is easy to understand that, if a firm has an improvement in its liquidity position as a result of a cyclical swing in earnings and finds it inconvenient to repay debt, it will invest the surplus. When the cash flow picture reverses, it will not have any surplus cash because of its previous action and will have to sell bills if it does not borrow. In spite of a number of efforts to do so, I believe no one has found a statistically significant relationship between short-term variations in bill yields and the distribution of corporate liquidity between cash and governments. That is to be expected in view of the considerations with respect to overhead costs given above. 
It does not follow that the trend in the ratio of cash to other forms of liquidity has not been influenced by interest rates. The share of liquidity in the form of time deposits (though still small) has risen since $195^{2}$, and that can probably be attributed to interest rates (though the willingness of banks to take corporate time deposits is also a factor).

The ratio of government security holdings to cash holdings has fallen since $195^{2}$ but, if we make allowance for the large proportion of governments held against tax liability, the ratio of cash to total liquidity has fallen from 75 to 72 per cent. That is a relatively small decline and does not constitute very impressive evidence of a large-scale switch from cash to bills.

The proportion of liquid assets held in the form of cash is of course influenced by other factors. An increase in efficiency in the use of operating cash works to reduce the ratio of cash to liquid assets. On the other hand, a reduction in protective liquidity resulting from a gain in confidence should tend to reduce bills relatively more than cash.

There is room, therefore, for some switch from cash to Treasury securities and time deposits, but there is no evidence that rising interest rates have produced a strong swing to interest-bearing forms of liquidity or that rising interest rates have accounted for a large part of the reduction in the ratio of corporate cash to sales and GNP.

\section{Cash Versus Other Forms of Liquidity in the Prewar Period.}

The ratio of corporate cash to total liquid assets rose slightly in the early years of the depression and then after 1933 rose to nearly 80 per cent of total liquidity. The shift must, I think, be put down to the very low levels of interest rates on time deposits and short-term government securities ruling in the late thirties.

The ratio of corporate cash to total liquidity in the r920's was higher than in the postwar period but, after adjustment of postwar data for tax liabilities, the cash liquidity ratio in the twenties was slightly higher than the one ruling in the postwar period.

The differences are not great enough to call for extended comment except to note that the development of Treasury bills does not seem to have had a great effect on the distribution of corporate liquidity.

Household Demand for Liquid Assets and Money

Demand for Liquid Assets.

Personal motives for holding liquid assets transactions and precautionary motives, liquidity preferences, risk avoidance-are all so familiar that it is not necessary to discuss them in any detail. Just as in the corporate case, an individual who holds liquid assets takes a reduction in expected yield on his portfolio in return for a reduction in risk and inconvenience. The loss in expected yield depends on the price difference between the expected yields of variable assets - real estate, stocks, longterm bonds - and the yields on liquid assets. Just as in the corporate case, we expect that, other things equal, the amount of liquid assets an individual will wish to hold will decline as the cost of holding them increases. We also expect that increased confidence in the future stability of income will reduce the demand for liquid assets, and vice versa. An increase in the variance of the expected performance of variable price assets will increase the demand for liquid assets, while a decrease will reduce it.

Some of the reasons for holding liquid assets are related to uncertainties or unevenness in the flow of receipts and expenditures. On that account we might expect the demand for liquid assets to increase, other things equal, with the level of permanent income. But liquid assets are also required in an optimum portfolio even when there is no problem of income or expenditure variation. Other things equal, then, we should expect the demand for liquid assets to grow with both the level of income and the level of assets.

In individual portfolio management the size of the portfolio has an important influence on the proportion of assets held in liquid form. That is so for two reasons. Since borrowing is costly and inconvenient, most people wish to hold enough liquid assets to provide for shortterm variations in income and expenditure. Persons whose total financial assets are small in relation to their incomes will find it advantageous to hold all their assets in liquid form. Second, asset management is an activity with 
decreasing costs to scale. The cost in terms of cash and effort of choosing assets subject to risk is much smaller per dollar invested for a large portfolio than for a small one. The net gain to be obtained from buying variable price securities as opposed to savings deposits of one type or another is not likely to be worth the trouble for the holder of a relatively small portfolio.

It seems probable that a substantial volume of liquid assets is held in connection with asset transfers. Individuals who sell marketable securities or real estate may hold funds pending reinvestment for periods ranging from a few days to several months. In some cases they may go liquid because they are bearish on variable price assets generally. But it is very common for people to sell a particular asset because they consider its net yield prospects unsatisfactory without having chosen another asset. They will hold liquid assets until they find a satisfactory alternative investment. We have no idea what volume of assets is tied up in this way but it may be very substantial.

Finally, there appears to be an interchange between strictly fixed-price assets - demand deposits, currency, savings deposits, and savings bonds - and assets with low credit risk and price variability, particularly high grade bonds. Individuals who have sufficient liquid assets to take care of short-term variations in income and expenditure may wish to have additional low-risk assets in their portfolio which they expect to hold for a fairly long time. The fact that savings deposits of various types can be converted to cash at any time with no transactions cost is of relatively little significance if one plans to hold an asset for a long time. Price variability is of some significance but those who plan to hold to maturity, anyway, need not give it a very heavy weight. Savings deposits of various types are therefore close substitutes for high quality bonds, particularly those with only moderately long maturities.

On that basis we should expect that, during periods when market yields on bonds are low relative to time-deposit rates, the flow of household funds into bonds would be relatively low and the flow into time deposits relatively high. Conversely, when bond yields rise relative to time-deposit yields, we should expect household bond purchases to rise relative to household takings of time deposits.

Of course the competitive relationship between time deposits and bonds is not just a cyclical phenomenon. The relative levels of time deposit yields and bond yields over the whole cycle will influence the division of individual portfolios. But because time deposit yields move slowly relative to market yields over the cycle (though linked in the long run to market yields), the cyclical influence of bondtime deposit substitution is much more apparent than any long-run substitution.

LIQUID ASSETS AND EXPENDITURE. A number of writers have expressed the view that variations in household holdings of liquid assets have a strong influence on the rate of consumer expenditure. The rationale of that view has never. been entirely clear to me.

It seems reasonable to expect that an increase in the real net worth of the household sector might tend to reduce saving and increase consumption. If people are saving in order to accumulate assets for some particular purpose, the desire to save may wane as they approach their goal. Of course, they may discover or recognize new goals for accumulation as they satisfy old ones, so it remains an empirical question whether an increase in net worth or in the ratio of net worth to income actually depresses saving.

But why should the possession of liquid assets, as distinguished from other assets, have a special effect on saving? One does not come any closer to any goal for accumulation by holding a deposit in a savings institution than by holding an equivalent amount of stocks and bonds.

The only difference seems to be that one can convert liquid assets into cash more easily and quickly than other kinds of assets. Consequently, one can give in to impulses to spend more easily if one holds liquid assets than if one holds other kinds of assets. There is some plausibility in that argument, but it obviously only applies to a limited part of the variation in liquid assets. The impulse consideration does not apply to persons who save regularly a substantial proportion of income or to persons who always have a substantial liquid position. For reasons which $\mathrm{I}$ will indicate below it seems 
likely that - except for the war and early postwar periods - most of the variation in liquid asset holdings is in the holdings of high income, high asset holders. In that case it is unlikely that cyclical variations in liquid asset holdings have much to do with variations in saving.

\section{Demand for Money.}

In the last section we discussed the demand for liquid assets as a group without any distinction between money and other liquid assets. We must now turn to the question why people hold part of their liquid assets in noninterestbearing demand deposits and currency. It should be noted at the outset that, in the literature, the reasons given in the last section for holding liquid assets are often given as reasons for holding demand deposits and currency. That may have been appropriate in periods when other forms of virtually riskless, readily marketable assets were not generally available. But it is not a satisfactory answer nowadays. The demand for currency and demand deposits must be analyzed, first, in terms of choices between liquid and nonliquid assets and, second, in terms of choices between currency and demand deposits and other forms of liquid assets.

DEMAND FOR CURRENCY. The total amount of currency outstanding since the war has varied between $\$ 25$ and $\$ 30$ billion. Estimates made by the Federal Reserve Board of Governors suggest that about one-third of this amount is in business hands and the rest either in the hands of households, lost, destroyed, or gone abroad. It is fairly obvious that the bulk of the currency in nonbusiness hands is not being used for pocket money or being carried around by people who do not have bank accounts. The amount of currency not in business hands represents nearly a month's wages for the entire labor force. Over half of American families have checking accounts and some of the remainder deposit pay checks in savings accounts and withdraw currency and registered checks as needed. Moreover, the bulk of the families who do not use bank accounts receive wages weekly. A full week's wages for one part of the families and an average of a couple of hundred dollars for the rest - which seems a generous estimate even after allowing for travelers - will not account for as much as \$10 billion of currency.

Some of the remainder is, no doubt, lost, destroyed, or gone abroad. The rest must be in hoards for some special reason. These would include currency used in illegal transactions or held by small businessmen and professionals who receive currency and hold part of it to evade taxes, and hoarded savings of farmers who saved during the war and distrusted banks.

The amount of currency outstanding nearly doubled during the depression and rose by a factor of about four during the war. After the war it fell slightly until I950 and has risen slowly since then by nearly $\$ 5$ billion. It should be noted that the amount of currency outstanding showed little trend in years from 1900 to I9I4, rose sharply during World War I, and then remained more or less stationary during the twenties.

If currency were used only for transaction purposes, we should expect the amount outstanding to rise with income but at a slower rate because of the increasing use of checking accounts, registered checks, the spread of check-cashing facilities, and the increased use of credit cards. We might also expect that currency held for tax evasion and illegal activities would grow with the scale of the economy - if the incentives for tax evasion do not change much.

On the other hand, it is likely that special factors connected with war resulted in the generation of abnormally high levels of hoarding relative to income and tax rate levels. The gradual liquidation of some of those wartime hoards may be offsetting the other factors tending to make the currency outstanding to grow. That position gains some support from the fact that the currency grew rapidly during World War I and then leveled off during the twenties, even though income grew. The rate of liquidation of currency hoards other than those connected with tax evasion or illegal activities may have been speeded up by the rise in interest rates, but we have no real information on that point.

HOUSEHOLD DEMAND FOR DEMAND DEPOSITS. We can approach the analysis of the demand for demand deposits by asking why a man, given that he has some liquid assets, should hold them 
in a form which yields no interest. Certainly a major part of the answer lies in the fact that checking accounts are more convenient than other liquid assets and that funds left with savings institutions for short periods yield no return or a very small one.

Persons who hold liquid assets against a certain or fairly probable excess of payments over receipts in the near future will not find the return from savings deposits or savings bonds worth the trouble of converting from cash to earning assets and back again unless the amounts involved are very large. The income transactions demand for money will certainly account for some substantial amount of personal demand deposits. As the savings deposit interest rate rises, the proportion of "transient" liquid assets held in the form of demand deposits should decline.

The full theory of an optimum demand deposit inventory policy is just as complex as any other kind of inventory policy, but a simple example suffices to make the point in question. Suppose we consider only the disposition of liquid assets held against known lump-sum outpayments to be made at known dates and which cannot be financed out of expected net cash inflows in the intervening period. A sum of $p$ dollars held for $m$ months yields the holder $p \times \frac{m}{\mathrm{I} 2} \times r$ dollars (when $r$ is the yield on savings deposits neglecting compounding). If an individual requires a given dollar return to make worthwhile one round trip from cash to savings deposit and back to cash, the size of the payment $p$ and the length of the interval $m$ required to earn that amount of dollars obviously becomes shorter as $r$ rises. When interest rates are low, savings deposits will be held only against large distant payments. As interest rates rise, people will hold savings deposits against smaller nearer-term payments which will produce a shift from demand balances to savings accounts.

It is unlikely, however, that the bulk of personal demand deposits are held for income transactions purposes. On January $3 \mathrm{I}$ (which is about the low point of the year for individual deposits), banks' records show that 85 per cent of personal demand deposit accounts had less than $\$ \mathrm{I}, \infty 00$, but those accounts had only about 30 per cent of the total amount of personal demand deposits. Since the larger holders have more than one account, it is probable that the remaining 14 per cent of the accounts were held by no more than ro per cent of the persons holding demand deposit accounts. And since nearly half of families have no demand deposit account it must be concluded that about 5 per cent of families own 70 per cent of personal demand deposits. Moreover, half the personal demand deposits are in accounts of over $\$ 5,000$.

No doubt some part of the relatively large deposits is required for income transactions. But it seems probable that a large proportion of the larger personal demand deposit accounts is held in connection with financial transactions.

At a rough guess, individual purchases and sales of stocks, bonds, real estate, and other assets amount to something like $\$$ roo billion per year. An average holding period - between sale of one asset and purchase of another - of about four months would tie up over $\$ 30$ billion. If half that sum were in demand deposits, \$r5 billion would be accounted for. I have no way of testing what amounts are tied up in asset float, but it seems probable that they are a significant part of personal demand deposits.

Now any individual who sells an asset and plans to reinvest in nonliquid assets, at a time some distance in the future or at an unspecified time, has the option of keeping his funds in a demand deposit or obtaining interest from a time deposit. Persons who plan to hold for periods less than a month cannot get interest from time deposits generally, and people in high tax brackets, who are interested only in capital gains, may not bother to try to get it. At low interest rates the proportion of people who will take the trouble to get time deposit interest in the circumstances under discussion is low. As rates rise, the proportion willing to take the trouble will rise and this will tend to shift funds (in relative terms) from demand deposits to time deposits.

A SUMMARY AND A MODEL. My conclusions on the relation of liquid assets to income, interest rate, and interest rate differentials may be summarized in the following way. 
I. Composition of portfolios. Persons whose total financial assets are relatively small will tend to hold them all in liquid form because the differential return from other forms of financial assets is too small to make the additional effort required worthwhile, and because the probability of occurrence of a situation requiring conversion of a large proportion of financial assets to cash is high.

Persons with larger portfolios of financial assets will divide them between liquid and nonliquid assets. The proportion held in liquid form will tend to increase if confidence in the stability of income deteriorates, if the differential between the expected net yield on nonliquid assets and that on liquid assets decreases, if the variance of the expected yield on nonliquid assets increases, if the ratio of total assets to income decreases. In particular, an improvement in confidence will tend to raise the value of stocks in relation to income and reduce the need for protective liquidity, thus tending to reduce the ratio of liquid "assets to total financial assets. A change in the differential between mortgage and high-grade bond yields will - if it persists long enough to be reflected in savings institution yields tend to cause a redistribution between holdings of savings deposits and near-liquid assets like high-grade bonds.

Since savings deposit yields move slowly, the differential between savings deposit yields and bond yields will reflect short-term movements of bond yields. A cyclical increase in bond yields tends to draw funds from liquid assets to bonds, and vice versa.

2. Liquid assets in relation to income. For a given state of confidence, relation of total financial assets to income, and given interest rate differentials, we should expect the liquid. asset holdings of persons with relatively large financial assets to grow from cycle to cycle in rough proportion to income.

For persons with relatively small total financial assets, our expectation about the liquid asset-income ratio is less clear. If changes in the liquid asset-income ratio do not influence the savings ratio then, over a decade in which the growth rate of income is above average, the ratio of liquid assets to income for small as- set holders should tend to fall. But, because the gross financial savings ratio varies not only with the total savings ratio but also with the amount of net investment in housing equity and the net flow of consumer credit, we cannot reach any very clear conclusion on the probable movements of the ratio of liquid assets to income for persons with small portfolios. We cannot, therefore, attach any great significance to observed movements in the ratio of liquid assets to income.

3. Money holdings versus liquid asset holdings. In general, we expect that as the yields on savings deposits rise, the proportion of liquid assets held in the form of demand deposits will decline. However, the relationship between interest rates and the distribution of liquid assets between demand and savings deposits will differ, as between different classes of people and as between assets held for different purposes. Finally, it should be noted that the yield on savings deposits should be interpreted to represent not only the rate of interest or dividend paid, but also the whole complex of advertising and selling efforts which may induce people to shift from demand to time deposits.

The whole position may be summarized in terms of a few very simple equations. Let us first divide households into high-asset and lowasset households. Low-asset households hold all financial assets in liquid form. One part of their liquid assets is held for purposes directly related to income and these "transactions" holdings are proportional to income; the remainder is a residual. The proportion of transactions assets held in the form of demand deposits is a decreasing function of a moving average of savings deposit interest rates (strictly speaking, separate rates for different types of institutions and different locations should be used - a single rate is used only as a shorthand device). The proportion of the residual liquid assets held in demand deposit form is also a decreasing function of savings deposit rates. In general, since the residual balances are by definition not needed for nearterm outlays, a smaller proportion of those balances will be held in demand deposit form than the proportion of transactions balances. 
Thus

$$
\begin{aligned}
& D D^{L}=D^{L}\left(\bar{r}^{s}\right) A y^{L}+D_{2}^{L}\left(\bar{r}^{s}\right)\left(L^{L}-A y^{L}\right), \text { where } \\
& D D^{L}=\text { demand deposits of low-asset holders } \\
& \bar{r}^{s}=\text { a moving average of savings deposit yields } \\
& y^{L}=\text { the income of the low-asset group }{ }^{3}
\end{aligned}
$$

The change in liquid assets of the low-asset group over any time period equals the gross financial saving of the group during the period $L^{L}=G F S^{L}$.

For the high-asset group, the same considerations govern the division of liquid assets between demand deposits and others, except that we should add a factor to allow for the asset transactions demand for liquid assets and eliminate the residual element. residential property but may show some tendency to rise when income rises rapidly. However, it would take us too far afield to discuss that point here.

\section{Movements of Household Holdings of Liquid Assets and Money in the Postwar Period.}

It is clear that if ( $I$ ) the ratio of wealth to income, (2) yields on nonliquid assets and on savings deposits and (3) the size distribution

$$
D D^{H}=D_{2}^{H}\left(\bar{r}^{s}\right) A y^{H}+D_{1}^{H}\left(\bar{r}^{s}\right) \times D_{3}\left(r^{M}-r^{s}\right) W^{H F}+\phi\left(r^{s}\right) \sum_{i=1}^{M} F\left(r_{t i}^{M}-\bar{r}_{t}^{s}\right) G F S_{t-i}^{H}
$$

when

$$
\begin{aligned}
& D D^{H}=\text { demand balances of high-asset holders } \\
& y^{H}=\text { income of high-asset holders } \\
& W^{F H}=\text { total financial wealth of high-asset holders } \\
& r^{M}=\text { net expected yield on marketable securities. }
\end{aligned}
$$

The final term is really another kind of asset float which arises from the fact that persons who normally make little use of savings deposits will take some time to shift from demand deposits to savings deposits, if they should accumulate liquid funds as a result of a decline in the attractiveness of securities.

The variable $W^{F H}$ will vary in proportion to income if the share of property income, valuation factors, and the concentration of income remain constant.

Gross financial saving for the higher-income groups should not be much influenced by variations in consumer credit or net investment in

\footnotetext{
${ }^{8}$ The question of permanent income arises here. When an individual's income declines and he remains a positive saver, he may keep his working cash balance unchanged, out of force of habit. If he becomes a negative saver (in cash-flow terms) he must draw down liquid assets and I should be inclined to think he would draw down his cash balance because he holds it to absorb fluctuations in expenditure relative to income. If aggregate income falls, we shall have three groups of people: (I) those whose incomes are unchanged and who, other things equal, keep cash balances unchanged; (2) those whose incomes fall but who remain positive cash savers - if their cash balances do not fall, the ratio of cash balances to current income rises the permanent income factor; (3) those whose incomes fall and who become negative savers, draw down cash balances absolutely and relatively to income. The buffer stock factors 2 and 3 affect the ratio of cash balances to income in opposite directions. For simplicity $I$ have written the equation as though the two effects cancel out.
}

of wealth are all constant, the ratio of demand deposits to income will tend to be constant except for minor fluctuations resulting from variations in the ratio of gross financial savings to income.

If the other conditions are satisfied while savings deposit yields have an upward trend, there will be a downward trend in the ratio of demand deposits to income.

Now suppose that there are short-run variations in interest rates as a result of changes in monetary policy and changes in economic activity. A fall in investment activity will be accompanied by a decline in corporate retained earnings and a rise in government deficit. In mild depressions such as we have had in the postwar period, there is little decline in gross financial saving. Changes in required reserve ratios make it possible for banks to bid for securities and drive down interest rates to induce households to reduce their purchases of securities and increase holdings of both demand and time deposits. When disposable income remains constant, the residual liquid assets of those with small portfolios will also rise and some part of this will take the form of demand deposits.

Of course, households, who withdraw from or are pushed out of marketable securities, 
shift their funds into savings deposits as well as into demand deposits (indeed, in the postwar period the increase in the flow into time deposits in recession years has been considerably greater than the increase in the flow of household funds into demand deposits). Since savings institutions hold little cash (unless we count reserve absorption by commercial-bank time deposits as the equivalent of cash), these funds come right back into the market and draw securities away from households. ${ }^{4}$ However, after a time, savings institutions begin taking mortgages on new houses and the increase in economic activity increases the transactions demand for cash.

Households go into cash and time deposits when interest rates fall, partly because bond yields are low relative to savings deposits yields, and partly because they expect a recovery and higher yields in the future. Some households, of course, speculate for a capital gain from a continued fall in interest rates, hoping to get out before the recovery. They, however, are usually bank financed and therefore merely supplement the demand for bonds generated by the expansion of bank reserves.

The process described above for the downswing works in reverse on the upswing, though not in an entirely symmetrical way. Rising levels of income will increase transactions balance requirements for liquidity, but a continued upward trend in the moving average of savings deposit rates works to lower the proportion of such balances held in demand deposit form. The same considerations apply to the effects of increasing total wealth. Thus, in the absence of a change in the level of yields on marketable securities, demand deposit holdings of households are likely to grow at a slower rate than income. A rise in household purchases of securities, associated with a rise in yields on marketable securities, may reduce both time and demand balances held as part of the asset float.

It seems to me that the analysis given above does conform fairly well to the actual experience of the postwar period. The ratio of total liquidity to personal income has shown no

\footnotetext{
t Secondary market purchases of mortgages from FNMA reduce federal issues of securities and, therefore, reduce the amount available for households.
}

trend since I952. Total liquidity (as defined here) has risen relative to income in recession years and fallen in booms. There has been a fairly obvious trade-off between time deposits and high-grade bonds - e.g., the "magic fives." The proportion of household liquidity in the form of currency and demand deposits has fallen steadily since $195^{2}$.

\section{Movements of Household Liquidity and De- mand for Money in the Prewar Period.}

Total household liquidity remained a fairly constant proportion of personal income from I 922 to 1927 but fell rapidly during 1928 and r929. The decline may be attributed to the large volume of new security issues floated and the general belief in the prospect of high net yields from investment in common stocks.

The level of liquidity in relation to personal income was lower (varying about a ratio of .6) than in the years since 1952 when the ratio of household liquid asset holdings to personal income has varied about a figure of .7. Some of the difference may be merely definitional since the treatment of high-grade bonds as an element in household liquidity is somewhat ambiguous. In addition, changes in income distribution have probably increased the share of financial saving by low-income groups who tend (for reasons given above) to hold all their financial assets in liquid form.

The most interesting and puzzling thing about the twenties is the steady reduction in the share of liquid assets held in the form of demand deposits and currency. In 1922, 38 per cent of household liquid asset holdings took the form of currency and demand deposits. By 1927 the proportion held in those forms had fallen to 30 per cent and by 1929 a further fall to 25 per cent had taken place. The sharp decline in household holdings of cash from I 927 to 1928 may be attributed to the rapid flow of household funds into common stocks. The furious pace of stock market activity resulted in a sharp reduction of the "asset float."

The decline in relative cash holdings in the earlier years is more difficult to explain. It was not due to rising yields on savings deposits because those yields were not rising. There is, however, some reason to believe that at least part of the shift resulted from changes in the 
competitive position of national banks with respect to time deposits. The establishment of differential reserve ratios for time deposits in I9 4 and the widening of national bank mortgage lending powers, together with the strength of the demand for mortgages in the early I920's, made time-deposit business attractive to commercial banks. It was generally believed during the 1920's that commercial banks encouraged customers to switch from demand to time deposits and even permitted checking against time deposits. It seems perfectly possible that increased nonprice competition for time deposits resulted in some redistribution of liquid assets between demand and time deposits. It is also possible that there was some shift from Liberty bonds to time deposits as a result of the decline in bond prices in 1920 . Since we did not include those bonds in liquid assets, a switch from bonds to time deposits would reduce the ratio of demand deposits to the liquid assets included in the ratios quoted above.

Those explanations appear a little ad hoc and the possibility of other explanations cannot be ruled out.

During the decade of the thirties the ratio of household liquid assets to personal income reached the high figure of 74 per cent in 1932 . The ratio then fell almost continuously until, by I94I, it had reached the 60 per cent level which ruled during the middle r920's. It seems reasonable to attribute the variation to changes in confidence particularly in the early part of the period.

The share of liquid assets held in the form of demand deposits and currency rose throughout the r930's, reaching 40 per cent by r94I. Since the yields offered for savings deposits declined throughout the period, there seems to be no special difficulty in explaining the rising share of demand deposits and currency in total liquidity.

\section{Conclusions.}

The household demand for liquid assets and money is a complex matter which does not seem to have a simple explanation. Without repeating what has been said above we may conclude that, putting aside short cycle movements, the distribution of income and the ex- tent of confidence in income stability are the major factors determining the demand for liquid assets in general. The distribution of liquid assets between demand and time deposits is significantly influenced by the efforts of savings institutions - through rate competition and other selling efforts - to obtain time deposits.

In the shorter cyclical movements, the volume of narrowly defined liquid assets held by households varies considerably with the variation in the difference between rate of return on time deposits and expected yield on marketable securities. Demand deposits holdings are also significantly affected by variations in expected yields on marketable securities.

Although demand and time deposits are competitive with one another, their short-run cyclical movements often tend to be positively correlated.

\section{Conclusions}

In this paper I have tried to do two things: (I) to review the major factors which seem likely to influence the amount and composition of liquid assets held by households and corporations; and (2) to examine the data over the last forty years to see whether they can be explained in terms of the factors discussed under ( $\mathrm{I}$ ).

The major conclusions for corporations are as follows:

(I) Short-run movements of corporate liquidity are strongly influenced by variations in cash flow from operations - most of these variations are reflected in holdings of government securities rather than in holdings of cash.

(2) The movement of total corporate liquidity during the r930's suggests a fairly strong connection between business confidence and ratio of liquid-asset holdings to activity.

(3) The decline in the ratio of corporate liquidity to sales in the years since $195^{2}$ is partly attributable to the decline in tax liabilities but also to improved cash management, and confidence in income stability.

(4) Corporate holdings of liquid assets respond fairly strongly to short-run changes in interest rates.

(5) There is no indication that the division of liquid assets between cash and other liquid 
assets responds to short-run changes in bill rates.

(6) After allowance for the effect of changing tax liabilities, there has been only a slight downward trend in the proportion of liquid assets held in cash. The rise in interest rates since 1952 therefore appears to have had little effect. However, it may be that improvements in cash management have been due to rising interest rates, while reduction in liquidity in other forms was due to improved confidence. In that case, changing interest rates may have had some influence on the distribution of liquid assets.

(7) During the depression of the thirties the proportion of liquid assets held in cash did rise as interest rates fell. It therefore appears that the elasticity of cash holdings to interest rates is greater at low interest-rate levels than at high ones.

The conclusions with regard to households can be summarized as follows:

Short-run movements of household liquidity show considerable response to short-run changes in net expected yields in marketable securities. A large part of this response is reflected in timedeposit holdings but demand deposits also respond.

Total liquid asset holdings responded to changes in confidence during the I930's in the same way that corporate holdings did.

The division of liquid asset holdings between cash and time deposits appears to have responded to changes in yields on savings deposits and to changes in the advertising and selling efforts of savings institutions.

\section{COMMENT}

Kenneth J. Arrow,

Stanford University

James Duesenberry in his encyclopedic coverage of the movements of holdings of cash and of liquid assets has listed many factors, but three elements appear and reappear: increasing returns to scale in transactions (whether between cash and other liquid assets or between liquid and nonliquid assets); the conveniences of having cash (and, by derivation, the conveniences of liquidity in terms of ease of acquiring cash as needed); and risk aversion. I will state some results in theory of choice under uncertainty which bear on the more precise interpretation of these elements and their implications for behavior.

Two branches of the theory of choice under uncertainty will be drawn on here: stochastic multiperiod inventory theory and the theory of risk aversion.

\section{Implications of Inventory Theory}

There has developed in the last fifteen years a theory of optimal behavior for the holding of inventories, where the firm is facing repeated uncertain demands and has repeated opportunities to purchase inventories. ${ }^{1}$ In its simplest

${ }^{1}$ See $\mathrm{P}$. Massé, Les réserves et la régulation de l'avenir, Paris, Hermann \& Cie., I946; K. J. Arrow, T. E. Harris, form, we assume discrete time periods. At the beginning of each period, the firm has a given stock of inventory. It is then faced with a demand, which is a drawing from a probability distribution. The demand is met, at least to the extent possible, and there is a penalty for the shortfall, if any. The firm then places an order for as much more stock as it wishes, and the new order, plus whatever stock may have been left over after meeting the demand, constitutes the stock on hand at the beginning of the next period. The cost for the period is the sum of the penalty and the ordering cost (plus possibly also storage cost); this is a random variable, since both the penalty and the amount ordered may depend on the random demand. The aim of policy is to minimize the sum over time of discounted expected costs.

Two observations may be made on these assumptions. In the first place, since only the expected value of returns is considered, we are assuming risk neutrality. This is an assumption appropriate for a large corporation, where the risk is divided and, in general, small for each stockholder relative to his total wealth, but not for an individual.

and J. Marschak, "Optimal Inventory Policy," Econometrica, I9 (1951), pp. 250-272 ; K. J. Arrow, S. Karlin, and H. Scarf, Studies in the Mathematical Theory of Inventory and Production, Stanford University Press, I958. 
In the second place, the whole problem arises because goods cannot be procured instantaneously, at least not without extra cost. If stock, could be ordered after the demand is known, there would be no costs beyond the irreducible minimum for ordering the goods. One interpretation of the penalty is the price of immediate delivery of the goods, which is higher than the ordering cost for lagged delivery. The difference between the penalty and ordering costs is a form of transaction cost, which we may term a timed transaction cost.

The interpretation of the inventory model relevant for the present discussion is that in which the good in question is cash or possibly liquid assets, and the firm is subject to random demands for cash, which cannot be replenished immediately without additional cost. $^{2}$ The optimal policy depends on the nature of the ordering cost function. If cash can be obtained at a cost proportional to the magnitude demanded (constant marginal cost), the optimal policy is to set a target level of cash and then, in each period, after the demand, acquire enough cash to bring the stock up to the target level. The target level depends on the penalty for shortfall, the rate of interest (which is the penalty for excessive holdings of cash), and the probability distribution of demand. The fluctuation in the observed cash holdings, especially if the observation is made just after the demand has occurred, will indeed, as Duesenberry notes, reflect primarily the fluctuations in demand. However, the target may change because of changes in the rate of interest; it may also change because of changes in the subjective probability distribution of demands, which in turn may be influenced by the observations. The latter movement will be relatively slow, since conviction of a change in the probability distribution will only be obtained after a series of observations confirm it.

A second case is that in which the ordering cost contains a fixed component as well as a proportional one. However, the ordering cost is zero if no order is placed. This corresponds

\footnotetext{
2 The model analyzed by $\mathrm{D}$. Patinkin (in Money, Interest, and Prices, Evanston, Illinois, Row, Peterson, r956, $\mathrm{Ch}, \mathrm{VII}$ ) is similar to a one-period version of the above model; there may be a whole sequence of demands and payments at random times within a period in which no cash replenishment at all can be carried out.
}

to a psychic cost of decision making or to administrative cost or to some other form of economies of scale in handling cash. This is again a transaction cost but of a different kind from timed transaction costs; we may call it a fixed transaction cost, in that it does not depend on the magnitude of the transaction. ${ }^{3}$

The optimal policy here is of the two-bin or $S, s$ type, to use the terms in the literature. There are two levels, a target, $S$, and a reorder point, $s$; cash is acquired only if reserves fall below $s$, but when they do, enough cash is acquired to bring the stock up to $S .{ }^{4}$ As can be seen, this implies a stickiness in the response to falling cash reserves; only beyond a certain level is there a response, but the response is apt to be large. The difference, $S-s$, which is roughly the size of the order (actually the order is usually somewhat larger), is under certain conditions roughly proportional to the square root of mean cash demands.

\section{Risk Aversion}

In this section, I will assume the absence of transaction costs and consider the effects on the demands for cash and for liquid assets of risk aversion. The model is a modified form of that studied by Tobin. ${ }^{5}$ It is basically a study of the choice between risky and safe assets; in interpretation it is perhaps more suited to analysis of the margin between liquid and nonliquid assets than between cash and liquid assets, since transactions motives are more significant in the latter choice.

We use the expected-utility hypothesis of behavior under uncertainty; that is, the individual makes choices so as to maximize the expected value of a suitably chosen utility function for wealth. One implication of the expected-utility hypothesis is not always under-

${ }^{3}$ The distinction between transaction costs which depend on the magnitude of the transaction and those which do not appears (in a nonstochastic context) in J. Tobin, "InterestElasticity of Transactions Demand for Cash," Review of Economics and Statistics, 38, 1956, pp. 24x-247.

"Although the policy had been discussed a good deal in the literature, the first proof of the optimality of the $S, s$ policy under reasonably general conditions is due to my colleague, H. Scarf, "The Optimality of the $(S, s)$ Policies in the Dynamic Inventory Problem," in K. J. Arrow, S. Karlin, and P. Suppes, Mathematical Methods in the Social Sciences, 1959, Stanford University Press, r960, pp. 196-202.

${ }^{5} \mathrm{~J}$. Tobin, "Liquidity Preference as Behavior Toward Risk," Review of Economic Studies, 26, 1958, pp. 65-86. 
stood; the utility function must be bounded, for otherwise a version of the St. Petersburg paradox could be found (this point was originally developed by the mathematician, Karl Menger). If $X$ is wealth and $U(X)$ is the utility function, then we suppose, of course, that $U(X)$ is strictly increasing; from the boundedness, it must approach a finite upper limit as $X$ approaches infinity and a finite lower limit as $X$ approaches zero. From the first of these, it is clear that on the average there must be risk aversion, i.e., $U^{\prime \prime}(X)$ (the second derivative) must be negative except, at most, for isolated intervals. It will be assumed here that individuals are risk averters throughout.

The quantity $U^{\prime \prime}(X)$ is not itself a suitable measure of risk aversion, since it depends on the units in which utility is measured. Two measures will be used here: (I) relative risk aversion, defined as $-X U^{\prime \prime}(X) / U^{\prime}(X)$, which is also the elasticity of the marginal utility of income, and (2) absolute risk aversion, defined as $-U^{\prime \prime}(V) / U^{\prime}(X)$. The first will be the more important.

The boundedness of the utility function has the following consequence; the relative risk aversion must approach a limit greater than I as $X$ approaches infinity, and a limit less than I as $X$ approaches zero. (This may be made clearer by noting that the logarithmic utility function, which is unbounded at both ends, has a relative risk aversion constantly equal to I.) If, for simplicity, we assume that the relative risk aversion is monotonic, then it must be monotonic increasing. In a sense, safety is a luxury good.

The choice model is that introduced by Tobin; the notation differs somewhat. Let $A$ be the initial wealth of the individual. He can invest all or some with a random rate of return $R$; the remainder, he leaves in cash with a certain rate of return of zero. The model can easily be extended to the case where there is a secure asset with a positive rate of return; in that case $R$ is interpreted as the difference between the random and the secure rates. This interpretation applies to the choice between liquid and risky assets. Let $a$ be the amount invested. Then the wealth at the end of the period is,

$$
a(\mathrm{I}+R)+(A-a)=A+a R,
$$

and the individual seeks to maximize,

$$
E[U(A+a R)],
$$

where $a$ must lie between $O$ and $A$. It can be shown that the optimal investment $a$ is necessarily positive if and only if $E(R)$ is positive; an individual will always take some part of a favorable risk but, if a risk averter, will never take any part of an unfair risk. The optimum might involve investing the entire initial wealth. If it does not, the optimal investment satisfies the condition,

$$
E\left[U^{\prime}(A+a R) R\right]=0 .
$$

We are interested in the demand for risky investment, $a$, and its complement, $m=A-a$, the demand for cash or liquid assets. First, we consider the effects of initial wealth $A$. If absolute risk aversion is increasing, then it can be shown that $a$ decreases as $A$ increases, that risky investment is an inferior good. Since this result is certainly empirically implausible, we must reject the hypothesis of increasing absolute risk aversion. It may be noted that the quadratic utility function, often used for its simplicity, implies increasing absolute risk aversion and so must be rejected. If, on the other hand, we assume decreasing absolute risk aversion, then risky investment becomes a normal good.

Decreasing relative risk aversion, which is a natural assumption, as we have seen, has a very interesting implication; the wealth elasticity of the demand for cash or liquid assets is greater than I, so that money and liquid assets are luxuries. Although the detailed empirical meaning of this implication requires further examination, particularly because of the neglect of transaction costs, it corresponds to the empirical work of Friedman and of Selden. ${ }^{6}$

These results have referred to wealth effects; one might also ask about price effects. Under uncertainty, the analogue of a price is the probability distribution of $R$ and, of course, there are many possible ways a distribution can change. A simple upward shift by a constant

\footnotetext{
'Friedman, "The Demand for Money: Some Theoretical and Empirical Results," Journal of Political Economy, 67, 1959, pp. 327-35I; R. T. Selden, "Monetary Velocity in the United States," in Studies in the Quantity Theory of Money, M. Friedman, Ed., University of Chicago Press, 1956, pp. I79-257.
} 
amount (i.e., the mean increases while the distribution about the mean remains unchanged) can be shown to increase the demand for risky investment, as might be expected, provided that risky investment is a normal good. It may be noted that an increase in the rate of interest on the secure asset implies a downward shift in the distribution of the spread, $R$, and so, again as might be expected, an increase in the demand for liquid assets.

A second type of shift in the distribution of $R$ is a simple multiplicative shift around zero. Here we have the simple and surprising result presented by Tobin; the risky investment is reduced in inverse proportion to the multiplier. Thus an ideal proportional income tax at rate $t$, which means a multiplier of $\mathrm{I}-t$, will increase investment in risky assets in the proportion, $\mathrm{I} /(\mathrm{I}-t)$.

Finally, we can consider a multiplicative shift around the mean instead of around zero, which might be thought of as a pure change in dispersion. This can be regarded as a compounding of the two previous shifts, a multiplication around zero, followed by an additive shift to restore the mean to its original value. It follows that an increase in dispersion, in this sense, will reduce the demand for risky investment (and increase that for liquid assets), provided that risky investment is a normal good.

\section{Phillip Cagan,}

Brown University

With James Duesenberry's paper as background, I should like to review what we know about the interest elasticity of monetary velocity in the short run. Several years ago the widespread belief that this elasticity might be very high led to strong misgivings about the effectiveness of monetary policy. This was one of the questions the Commission on Money and Credit was to deal with. It did not, at least not clearly. So I appoint myself to a commission of one to issue a supplementary report on this question.

The issue, you will remember, was whether changes in velocity owing to interest-rate movements induced by open market operations might largely offset the effect of those operations and so prevent the Federal Reserve from restraining booms and mitigating recessions. The Radcliffe Report seems to suggest that the interest elasticity of velocity might be infinite, because of a ready supply of money substitutes, so that monetary measures are trapped in a swamp of unlimited liquidity. This extreme view was heard much less in this country after our tight money period in 1955-56. The view still prevails that velocity changes can delay or subdue monetary measures though not offset them entirely.

Some defenders of monetary measures argued that such changes in velocity are welcome because they cushion the shock of monetary restraint. This is an ingenious counterattack but very misleading. We do not need this additional cushion; the economy has others. Those who need to borrow can always do so if they are willing to pay the going rate. To be sure, an elastic velocity is in a sense the market's way of softening the blow of monetary restraint. Accordingly, if velocity were completely inelastic, we should not feel deprived of a needed safety valve; the inelasticity of velocity would indicate that we did not need the valve. On this argument we might conclude that it doesn't matter how elastic velocity is.

An elastic velocity may cause problems, however. The timing, extent, and duration of induced changes in velocity may be difficult to predict and so make the effects of a given monetary action uncertain beforehand. This surely does not make it easier to stabilize the economy by monetary measures and may make it more difficult. I say "may" because changes in velocity occur frequently for many other reasons, and this additional source of change may not make monetary stabilization any more difficult than it would otherwise be. In statistical terms, the standard error of predictions of future changes in velocity may be larger (though not necessarily) when the interest elasticity of velocity is larger.

What does the evidence show about the size of this elasticity? Duesenberry is imprecise about the effects of interest rates on the demand for checking deposits, as he has to be in the kind of historical survey he presents. If I do not misread him, however, interest effects play a secondary role in his analysis, and this is so for periods in which the size of their move- 
ments was among the sharpest on record. He finds little reason for, and little evidence of, interest-rate effects on corporate cash balances, at least in the short run. For households, interest rates on savings deposits are important, though they are likely to have their main effects in the long run, both because households may adjust savings deposits slowly to changes in these rates and because these rates respond slowly to changes in bond rates. This all appears plausible to me from the data I have examined. He finds the main short-run effect of interest rates on demand deposits to be that of bond rates on the deposits of high-asset households, and even this effect is subdued because many of the households who move in and out of bonds probably keep their idle balances in savings accounts.

I come away from Duesenberry's paper, therefore, with the impression that the interest elasticity of velocity in the short run is not very high, or at least is likely to be much lower than in the long run. Perhaps he did not intend to give this impression; in any event, I see nothing in the evidence he covers to deny it and much to support it.

How do such findings square with other studies? We have first of all Henry Latané's well-known study showing an impressive longrun relationship between velocity and interest rates since 1909 . This study and others similar to it raised doubts in my mind, because they seemed to depend heavily on two large movements in velocity and interest rates from the I930's to the I950's without any indication that the shorter movements within this period showed the same relationship. Moreover, Latanés data do not appear to fit so well before World War I. Friedman's results suggest that long swings in velocity can be explained just as well by permanent income, though, as he indicates, his results may not be inconsistent with Latanés because of their different treatment of time deposits and also because permanent income may be a proxy for changes in interest rates. $^{1}$ My colleague Allan Meltzer reports a good fit of real cash balances to in-

${ }^{1}$ If $y_{p}=r_{p} W_{p}$ (where $y$ is real national income, $r$ "the" interest rate, $W$ real national wealth, and $p$ denotes "permanent" magnitudes), a change in $r_{p}$ will affect $y_{p}$ if it reflects a change in productivity of capital, and will affect $W_{p}$, if a change in the public's desire to hold wealth. terest rates for the entire period since 1900 using a concept of wealth instead of income as a deflator of money balances. When he uses permanent income as a deflator, he also gets a significant partial regression coefficient for interest rates, and does so for the period before I930.

These results suggest that there is an effect of interest rates on velocity in the long run. They are less clear, to me at least, on whether there is an effect in the short run. Scatter diagrams may show a short-run correlation to some degree, but this may be spurious, reflecting the tendency of velocity and interest rates to respond in a similar way to fluctuations in business activity. These correlation studies seem to give more consistent results over longer periods than over individual cycles and for long-term rather than short-term rates of interest, though these points need further clarification.

I may cite evidence of quite a different kind. In a study I made of seven hyperinflations, ${ }^{2}$ I found a lagged relation between velocity and the cost of holding money, where the cost in this case was the rate of change of prices. The lag was of the distributed type and had average lengths of nearly a year or more in most countries; moreover, the length appeared to decrease with the extent and duration of hyperinflation. If this evidence is carried over to normal times and applied to the effect of interest rates on velocity, the implication is that the effect has an average lag of several years or more.

My study, Duesenberry's paper, and other evidence I have seen appear to suggest that the short-run interest elasticity of velocity is smaller than the long-run elasticity. In Meltzer's study, the long-run elasticity is approximately unity, so the short-run elasticity may be considerably less than unity, depending on the time span. If so, cyclical fluctuations in velocity are not to be attributed to interest-rate movements, at least not entirely. Although there may be many serious obstacles to effective monetary measures, such as lags, poor forecasts of business conditions, and so on, off-

\footnotetext{
${ }^{2}$ In Studies in the Quantity Theory of Money, Milton Friedman, Ed., University of Chicago Press, 1956.
} 
setting changes in velocity may not be one of them. ${ }^{3}$

\section{IRWIN FRIEND,}

University of Pennsylvania

The description in this interesting paper by Duesenberry of the procedures followed in arriving at the conclusions given does not seem to me to be adequate to form an appraisal either of the approach followed or of the degree of success achieved. It is not entirely clear, for example, how the supply of liquid assets has been handled in his model nor how much variation he has been able to explain in what are apparently presumed to be demand relationships for liquid assets by corporations and households. I assume that this information will be forthcoming, but until it is, I can comment only on some of the specifics of the paper rather than on the more important general orientation. The paper incidentally would be made more useful by presentation of the basic data and key statistics, so that qualitative conclusions can be assessed and also comparisons with other findings can be effected.

In his discussion of short-run movements in corporate liquidity, Duesenberry finds that variations in corporate liquid assets are principally due to variations in cash flows from operations and only to a lesser extent to interest rates. There is no indication of any treatment of the influence of the level of current liabilities on liquid-asset holdings except for a constant percentage tax adjustment. It is not at all clear why tax liabilities are treated in this unique fashion and why the level as well as composition of other current liabilities is not considered to influence corporate liquidity, particularly since business firms are supposed to use the liquid asset - current liability ratio as one important measure of liquidity. More

\footnotetext{
a It is sometimes also argued that even a "low" interest elasticity of velocity is troublesome if the interest elasticity of investment is sufficiently low. Then a large change in interest rates is required to produce a given change in investment and, with even a low interest elasticity of velocity, an exceptionally large open market operation is required. It is further argued that a large operation may not be feasible for "institutional" reasons, but these reasons have never been clearly specified. Unless they refer to lags and the consequent danger of overshooting, it is hard to take them seriously.
}

generally, of course, the whole current and fixed-asset and liability structure would be expected to be relevant. The answer may be that Duesenberry has been able to explain virtually all variation in liquidity by the variables he has used, but this seems doubtful and in any case cannot be ascertained from his paper.

While apparently the corporate-bond yield is considered as one of the determinants of liquid-asset holdings of corporations, there is no indication that the cost of equity financing or the state of the equity markets has been considered in any systematic form. Thus, for example, it is not entirely clear why the $195^{2-}$ $6 \mathrm{I}$ rise in Baa bond yields might be expected to be associated with a decline in corporate liquidity, since presumably most firms would have considered that that rise in bond yields was associated with a sizable decline in the cost of equity financing. Also, when Duesenberry notes that "a one percentage point increase in the bond yield appears to reduce corporate borrowing by $\$ 700$ million per quarter," would not that rise in bond yields result in a partly offsetting increase in equity financing, even without any further adjustment for the fact that the cost of equity financing would normally be considered by business to be declining when interest rates are rising?

Duesenberry finds that the ratio of corporate liquidity to GNP during the twenties was higher than in the fifties. It is not clear whether he is relating corporate liquidity to GNP, as he states, or to income originating in the corporate sector which would appear to be more appropriate. However, the latter measure of corporate liquidity might even intensify the result he obtained. Duesenberry notes that the changes in the cost of liquidity or in confidence about income stability cannot be used to explain the difference in liquidity ratios between the two periods. I would not be inclined to discount completely the possibility that business in recent years has been appreciably less concerned about the danger of major depression than it was in the twenties. Three other factors which might help to explain at least part of the difference in liquidity between the two periods are, first and most important, the much greater burden of debt in the twenties; second, perhaps greater access to or willingness to use short- 
term bank financing, or both, in the fifties, at least in manufacturing; and third, perhaps the difference in the implications of tax liabilities. Since I just received Duesenberry's paper shortly before this conference, I have not had an opportunity to look into the relevant debt statistics, but I do recall that the ratio of interest payments to income before taxes and before interest was about 25 per cent in the late twenties and is perhaps one-half that currently, which might suggest a situation calling for higher liquidity in the earlier period. So far as the tax situation is concerned, it is not clear what tax adjustment was made or should have been in the twenties as compared with the fifties, but it is possible that the procedure followed might have distorted the comparison of liquidity ratios in the two periods. On the other hand, there are several possible reasons for expecting a lower conventional liquidity ratio in the twenties, including the influence of call loans and commercial paper.

Another question relating to the adjustment for tax liability relates to the discussion of the trend in relative importance of cash versus other forms of corporate liquid assets in the postwar period. Assuming, for want of information, that a constant percentage adjustment was made for tax liability, would this be appropriate over a period in the earlier part of which corporate tax payments due at the end of a year could be paid over the following year as a whole, while at the end of the period such tax payments had to be made in the first half of the following year?

Duesenberry also states in his discussion of the composition of corporate liquid assets that "no one has found a statistically significant relationship between short-term variations in bill yields and the distribution of corporate liquidity between cash and governments." Though this statement may very well be true, I am surprised at such a finding. In a paper, "The Effects of Monetary Policies on Nonmonetary Financial Institutions and Capital Markets," I prepared for the Commission on Money and Credit, in which I analyzed the demand for and supply of claims on different financial institutions, but without generally separating corporations from households, I found a highly significant effect, in the expected direction, of quarterly changes in the bill rate on the demand for idle demand deposits by the private sector, and also on the demand for federal securities by this sector. I would have guessed that this result reflected in good part a corporate response to changes in bill rates.

Turning to the discussion of household demand for liquid assets and for demand deposits, Duesenberry notes that such demand might be expected to increase with permanent income and discusses some theoretical possibilities of different types of response to changes in income. A considerable body of seemingly relevant survey data on the relation of household asset structure and saving to different types of changes in income exists and perhaps might be used. To give one such finding: ". . . families with fluctuating incomes (over a three-year period) do not seem to show much difference from families with constant incomes in their saving in the form of cash and deposits; there appears to be some tendency for the former to save less in cash and deposits than the latter at all income levels, though at high income levels families with fluctuating incomes might be expected from theoretical considerations to accumulate more cash and deposits than families with constant incomes." 1

In his interesting attempt to estimate asset float as a significant element in accounting for the level of personal demand deposits, Duesenberry notes that a large proportion of the more substantial personal demand deposit accounts is held in connection with financial transactions and approximates at "a rough guess individual purchases and sales of stocks, bonds, real estate, and other assets amount to something like $\$$ roo billion per year." This seems much too small, which would suggest that asset float is even larger than estimated by Duesenberry, thus strengthening his point, unless the average holding period has been correspondingly overstated. In I96I purchases plus sales of stock alone amounted to $\$ 170$ billion and while a sizable amount of this is broker-dealer or institutional, and $x 96 x$ is considerably higher than the average of preceding years, the household sector alone in recent years (excluding

\footnotetext{
${ }^{1}$ Irwin Friend and Stanley Schor, Consumption and Saving, Vol. II, University of Pennsylvania Press, 1960, p. 272 .
} 
broker-dealers and institutions) must have had an average amount of stock purchases plus sales of well over \$roo billion in I96r and perhaps $\$ 75$ billion annually in the late 1950's. I have not had the opportunity to make a rough estimate of the other items, but my guess is that they amount to very much more than $\$ 25$ billion. I am assuming, incidentally, though Duesenberry does not make clear where he treats the demands of financial institutions, that they are not included in the household sector; otherwise the apparent understatement of float would be more serious. The figure for gross financial transactions of the household sector is of course the least unreliable of the estimates required to derive asset float in the form of demand deposits. Duesenberry notes that the sharp decline in household holdings of cash in the late twenties may be attributed to a sharp reduction of asset float associated with the "furious" pace of the stock market. This seems questionable in view of the enormous increase in the volume of stock and other financial transactions even if there were an appreciable reduction in the average holding period between the sale of one asset and the purchase of another.

In the one place in his paper where Duesenberry does present an explicit model, i.e., where he discusses the determinants of money holdings versus other liquid assets for the household sector, it is not at all clear how a key financial asset such as stock is supposed to affect demand balances. It would appear that the market value of stock enters as an exogenous explanatory variable for demand behavior of high-asset holders but not at all for small-asset holders.
Liabilities and real assets apparently are presumed to have no effect on demand balances for any group of asset holders. Insurance is apparently assumed to have no effect on demand behavior at least for low-asset holders. It is not clear whether the yield variables are supposed to be adjusted for expected price level changes, where this is relevant, or how changes in risk evaluation or in uncertainty are handled. Though gross financial saving is introduced as a relevant variable in explaining demand deposits of high-asset households, Duesenberry concludes that, other things being equal, there will only be "minor fluctuations [in the ratio of demand deposits to income] resulting from variations in the ratio of gross financial savings to income." This apparently means that the coefficient of gross financial savings is very small since such saving, assuming it is comprised of currency and deposits, savings shares and securities, is quite variable in relation to income.

So far as his general conclusions are concerned, it is difficult to assess such statements as, ". . . the distribution of income and the extent of confidence in income stability are the major factors determining the [household] demand for liquid assets in general," without more background quantitative information than is supplied. Thus I was not able to compare Duesenberry's interest rate effects on the level and composition of liquid assets with related results reported in the CMC paper I referred to earlier or with other results. However, qualitatively, his major conclusions for the corporate and household sectors seem for the most part to be reasonable. 